\title{
Effects of topical gel formulation of Ficus carica latex on cutaneous leishmaniasis induced by Leishmania major in BALB/c mice
}

Ali Pouryousef ${ }^{1}$, Erfan Eslami', Sepehr Shahriarirad ${ }^{2}$, Sina Zoghi ${ }^{2}$, Mehdi Emami $^{2}$, Mohammad Reza Cheraghi $^{2}$, Bardia Zamiri ${ }^{2}$, Soliman Mohammadi-Samanii ${ }^{3}$ and Bahador Sarkari ${ }^{1,4^{*}}$ (D)

\begin{abstract}
Objectives: The current study aimed to evaluate the effects of Ficus carica latex on the treatment of cutaneous leishmaniasis (CL), induced by Leishmania major. A 5\% topical gel with F. carica latex was prepared. BALB/c mice were infected by inoculation of amastigotes form of $L$. major. Thirty BALB/C mice were divided into five groups, where the first group was treated daily, the second group twice per day, and the third group every other day with the 5\% topical gel, for 3 weeks. The sizes of the lesions were measured before and during the course of treatment.

Results: Although the mean size of lesions in the mice group treated with the 5\% F. carica gel, especially in the group receiving daily treatment, was less than the mean size of the lesions in the control group, yet, the differences was not statistically significant ( $p>0.05$ ). The findings of the current study demonstrated that the $5 \% \mathrm{~F}$. carica latex with a 3-week course of treatment had no considerable effect in recovery or control of $\mathrm{CL}$ induced by L. major in the murine model. Using higher concentration of F. carica latex and with longer treatment lengths may increase its efficacy in the treatment of $\mathrm{CL}$.
\end{abstract}

Keywords: Ficus carica, Latex, Cutaneous leishmaniasis, Leishmania major

\section{Introduction}

Despite the great advances in the diagnosis and treatment of cutaneous leishmaniasis (CL), the disease is still one of the most important health challenges in many countries around the world.

With diverse clinical manifestations, $\mathrm{CL}$ is endemic in many countries in the Americas, the Mediterranean Basin, Middle East, and Central Asia [1-6]. Approximately $90 \%$ of CL cases occur in Iran, Afghanistan, Algeria, Iraq, Saudi Arabia, Syria, Brazil, and Peru. In Iran, both visceral and cutaneous forms of the disease are present $[4,5,7-9]$. Treatment of CL remains

\footnotetext{
*Correspondence: sarkarib@sums.ac.ir; sarkarib@yahoo.com

1 Department of Parasitology and Mycology, School of Medicine, Shiraz

University of Medical Sciences, Shiraz, Iran

Full list of author information is available at the end of the article
}

a challenge and the pentavalent antimonials, which are still the mainstay for treatment of $\mathrm{CL}$, are relatively toxic, require many injections and are not always effective [10-12]. Therefore, finding new compounds for the treatmentof this disease seems necessary. In traditional medicine several native plants have been used for the treatment of CL $[13,14]$. Among these are garlic, shallots, wormwood, yarrow, walnuts, thyme, henna plant, mimosa, aloe, which are having, to some extent, antileishmanial effects [13].

Ficus plants belongs to Moraceae family and consist of extremely different plants. Ficus carica is an Asian species of fig, well-known as the common fig. The fig fruit is considered to be beneficial in traditional medicine in the treatment of various diseases including diabetes, warts, cancer, and gastrointestinal disorders [15]. The latex of the plant is milky white and is

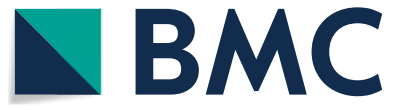

(c) The Author(s) 2021. This article is licensed under a Creative Commons Attribution 4.0 International License, which permits use, sharing, adaptation, distribution and reproduction in any medium or format, as long as you give appropriate credit to the original author(s) and the source, provide a link to the Creative Commons licence, and indicate if changes were made. The images or other third party material in this article are included in the article's Creative Commons licence, unless indicated otherwise in a credit line to the material. If material is not included in the article's Creative Commons licence and your intended use is not permitted by statutory regulation or exceeds the permitted use, you will need to obtain permission directly from the copyright holder. To view a copy of this licence, visit http://creativeco mmons.org/licenses/by/4.0/. The Creative Commons Public Domain Dedication waiver (http://creativecommons.org/publicdomain/ zero/1.0/) applies to the data made available in this article, unless otherwise stated in a credit line to the data. 
used, by several indigenous communities, as a curdling agent in the production of milk product like cheese and yoghurt [16]. Numerous bioactive compounds including phenolic compounds, namely, psoralen and bergapten, phytosterols, free amino acids, saturated and unsaturated fatty acids, phytosterols, and cysteine are present in the $F$. carica latex. Besides, the fig's latex is a rich source of proteolytic enzymes, among them is ficin $\mathrm{S}$ which is a well characterized sugar containing proteinase. Ficus latex is also reported to have several other enzymes, including lipase, catalase, peroxidase, protease, rennin, diastase, and esterase [16-19].

The latex of fig shows antioxidant, antifungal, chitinolytic, cytotoxic, antiviral, antibacterial and anthelmintic activities $[15,20-25]$.The active compounds of Ficus latex responsible for its antimicrobial activity has been reported in some studies. It has been shown that the chlorophormic, ethyl acetate, methanol, and hexanoic extracts of latex has antifungal activities against Aspergellus fumigates, Trichophyton rubrum, Trichophyton soudanense, Microsporum canis, Scopulariopsis brevicaulis, Candida albicans, and Cryptococcus neoformans [15]. The antifungal property of $F$. carica latex has been attributed to its chitin-binding protein [26]. Two natural furocoumarins of $F$. carica latex, 5-methoxypsoralen and 8-methoxypsoralen, has shown significant toxic effect against larvae of Aedes aegypti [27]. Moreover, cysteine proteinases of $F$. carica latex are known to be significantly effective against rodent intestinal nematodes, including Heligmosomoides polygyrus and Trichuris muris [28]. Also, the anthelmintic activity of $F$. carica latex against Syphacia obvelata, have been documented [22].

Considering the antibacterial and antifungal properties of $F$. carica latex, the current study aimed to evaluate the anti-leishmanial effects of $F$. carica latex for the treatment of CL, induced by L. major in BALB/c mice.

\section{Methods}

\section{Preparation of $F$. carica latex gel}

The latex of $F$. carica was obtained from the fig tree in summer, 2020, in Fars Province, southern Iran. Fifty mL of the latex was freeze-dried which was somewhat gelatinous. To prepare a $5 \%$ gel of $F$. carica latex, the lyophilized latex was levigated with Eucerin in a 1:9 weight ratio, according to the geometric method, and homogenized following by mixing with an equal volume of petrolatum. The final product was kept in an adequate jar in a dark and cool place until use. The choice of latex concentration was based on the fact that in previous studies on the effect of fig latex on other microorganisms including fungi and viruses, these concentrations were considered to be effective.

\section{Inoculation of BALB/c mice with Leishmania parasites}

Thirty inbred female BALB/c mice (4-week-old, 25-30 g body weight) were obtained from Pasteur Institute, Tehran, Iran. The animals were kept in condition with a 12:12-h dark-light cycle, $40-50 \%$ humidity, at $25 \pm 3{ }^{\circ} \mathrm{C}$ temperature. Free access to water and a standard diet was provided for the animals. L. major (MRHO/IR/75/ER) was used in this study. Mice infection was done by subcutaneous inoculation of amastigotes form of $L$. major, ( $0.2 \mathrm{~mL}$ of a suspension containing $4 \times 10^{6}$ amastigotes) into the top of mice's tail base by insulin syringe. The cutaneous lesions were developed after about 4 weeks of inoculation.

\section{Treatment with F. carica latex topical gel}

The thirty $\mathrm{BALB} / \mathrm{c}$ mice were divided into five groups (six mice in each group). The first group received 5\% gel, daily, the second group received the gel twice a day, and the third group received the gel every other day. The duration of treatment in all groups was 3 weeks. The positive and negative controls received amphotericin B (intramascular, daily) and the gel base, respectively. The size of the lesion was measured with a direct reading digital Vernier caliper, before and during the course of treatment. At the end of the treatment period, a skin sample from the lesion area was taken and evaluated for the parasite load, using the methods described by Ezatpour et al. [29]. Briefly, lesions were cleaned with $70 \%$ ethanol and smears were prepared by the sterile lancet, fixed by methanol, and stained with Giemsa stain. The load of parasites was determined, considering the following guideline. Negative: 0 parasite/10 fields, $1+: 1$ parasite/10 field, $2+: 1-10$ parasites/10 fields, $3+: 10-100$ parasites/10 fields, $4+: 1010-1000$ parasites/10 fields, $5+$ and more: more than 1000 parasites/10 fields. The animals were euthanized at the end of experiment, using ketamine-xylazine $(100 \mu \mathrm{L}$ of a 10:1 ketamine-xylazine solution, IP).

\section{Statistical analysis}

The mean sizes of the lesions in the five groups of mice were analyzed by SPSS (ver. 20). Nonparametric Kruskal Wallis test was used to find out the mean differences of the size of lesions in the five groups of studied mice. The pre-intervention measures (time $=0$, before treatment) were used for adjustment of trend and grouping comparison. Significance was established for a P-value of $<0.05$. 
Table 1 Mean sizes of $\mathrm{CL}$ lesions ( $\mathrm{mm}$ ) in BALB/C mice before and during the treatment with F.carica latex gel

\begin{tabular}{llllll}
\hline Group of mice under treatment & Before treatment & First week & Second week & Third week & p-value \\
\hline Positive control & $6.57 \pm 0.85$ & $6.31 \pm 0.69$ & $6.3 \pm 0.78$ & $6.28 \pm 1.05$ & 0.073 \\
Negative control & $7.74 \pm 1.07$ & $7.86 \pm 0.93$ & $8.12 \pm 1.2$ & $8.27 \pm 1.16$ & 0.125 \\
Test (once daily) & $6.5 \pm 1.08$ & $6.6 \pm 1.41$ & $6.37 \pm 1.28$ & $6.45 \pm 1.33$ & 0.152 \\
Test (twice daily) & $5.73 \pm 0.81$ & $6.1 \pm 1.36$ & $6.3 \pm 2.16$ & $6.35 \pm 2.56$ & 0.168 \\
Test (every other day) & $6.8 \pm 0.35$ & $6.79 \pm 0.38$ & $6.78 \pm 0.84$ & $6.79 \pm 1.13$ & 0.085 \\
\hline
\end{tabular}

All data are presented in mean \pm SD

\section{Results}

The mean sizes of leishmanial lesions during the 3 weeks of the study for different treatment regimens of the $5 \% \mathrm{~F}$. carica gel and the negative and positive control groups are presented in Table 1. Although the mean size of lesions in the mice group treated with the $5 \%$ F. carica gel, especially in the group receiving daily treatment, was less than the mean size of the lesion in the control group, yet, the differences were not statistically significant ( $p>0.05)$. The post-hoc comparison suggests that there is a difference in favor of daily treatment with $5 \%$ gel, as the most effective treatment regimen, yet the difference was not statistically significant $(P>0.05)$. Direct smears of lesions in the microscopic investigations were positive for the Leishmania amastigotes, after 3 weeks of treatment in all control and experimental groups. The microscopic examination of the smears prepared from the mice skin lesions showed a lower parasite load in the positive control group and the gel receiving group in comparison with the negative controls.

\section{Discussion}

Pentavalent antimony compounds remain the drug of choice for the treatment of CL as well as other forms of leishmaniasis. Nevertheless, treatment with antimony agents has been associated with several challenges, including toxicity and drug resistance [10]. Therefore, finding new compounds for the treatment of leishmaniasis is a serious necessity that has attracted the attention of many researchers. In the current study, the anti-leishmanial effect of $F$. carica latex, on $L$. major was evaluated. Results of the study demonstrated a reduction in lesion sizes in BALB/c mice treated daily with the 5\% gel of the latex, but the differences were not statistically significant when compared with the control groups. The findings indicated that the $5 \%$ concentration F. carica latex in topical gel formulation has no substantial effects on inhibiting the growth of the parasite. These findings are in agreement with the study of Saleem et al. in which the aqueous extract of $F$. carica had weak in vitro activity against the intracellular form of both $L$. donovani and
L. major [30]. The low concentration of latex and shortterm treatment period might play an important role in obtaining such a result in our study. This means that preparing a gel with a higher concentration or extending the duration of treatment may have better results. However, higher concentration of latex may have toxicity for the host as documented by Alziro et al. where they showed that the $F$. carica latex in a dose of $3 \mathrm{ml} / \mathrm{kg} /$ day had a high toxicity effect on studied mice [22].

Another reasons of inefficiency of fig's latex in the treatment of CL in the present study can be attributed to the harvesting time of fig's latex, as the latex has different levels and compositions at different times of plant and fruit growth. Support from this notion comes from Raskovic et al., study which reported that the highest chitinolytic activity of the fig's latex is at the beginning of flowering and the highest antifungal activity is in spring [31].

Another concern about the application of fig's latex is the irritating properties of its compounds, which have been reported in various studies. The irritating effects of fig latex is linked to the presence of compounds such as calotropenyl acetate, methyl maslinate, and lupeol acetate in it [32]. However, in the present study, no apparent irritating effect was observed in the studied mice. This may be due to the relatively low concentration of the used latex in this study and the dissolution of the irritating lipid compounds in the petrolatum, used for the preparation of the gel.

In the present study, the sizes of leishmaniasis lesion in positive control mice before and after treatment did not show a significant difference. This may be due to the resistance of the strain to the drugs which has been used in the study in the treatment of CL.

\section{Conclusion}

The $5 \%$ concentration of $F$. carica latex had no considerable effect in the treatment of $C L$ induced by $L$. major in the BALB/c mice. Further studies, using higher doses of $F$. carica latex and with longer treatment lengths may 
increase the efficacy of $F$. carica latex in the treatment or control of CL. In addition, better results may be achieved by preparation of latex in different plant growth seasons.

\section{Limitations}

There are several limitations to this study. First, there was no improvement in the positive control mice despite treatment. Second, the gel was used in a limited dose. Lastly, the length of treatment could be longer.

\section{Abbreviation}

$\mathrm{CL}$ : Cutaneous leishmaniasis.

\section{Acknowledgements}

The study was the subject of MD dissertation of Dr. Erfan Eslami.

\section{Authors' contributions}

BS, AP, SMS, and EE conceived and designed the study; SS, SZ, ME, PC and BZ collected the samples and performed the laboratory works; AP and EE prepared the first draft of the manuscript. All authors read and approved the final manuscript.

\section{Funding}

This study was supported by a grant from the vice-chancellor for research of Shiraz University of Medical Sciences, Shiraz, Iran (Grant No. 95-01-21-12586).

\section{Availability of data and materials}

Any further requested information regarding the experimental and data analysis during the current study is available from the corresponding author on request.

\section{Declarations}

Ethics approval and consent to participate

The protocol of this study was approved by the Ethical Committee of Shiraz University of Medical Sciences (Sums), ethical reference No. IR.SUMS. REC.1397.062)

\section{Consent for publication}

Not applicable.

\section{Competing interests}

The authors declare that they have no competing interests.

\section{Author details}

${ }^{1}$ Department of Parasitology and Mycology, School of Medicine, Shiraz University of Medical Sciences, Shiraz, Iran. ${ }^{2}$ Student Research Committee, School of Medicine, Shiraz University of Medical Sciences, Shiraz, Iran. ${ }^{3}$ School of Pharmacy, Shiraz University of Medical Sciences, Shiraz, Iran. ${ }^{4}$ Basic Sciences in Infectious Diseases Research Center, Shiraz University of Medical Sciences, Shiraz, Iran.

Received: 6 March 2021 Accepted: 13 May 2021

Published online: 22 May 2021

\section{References}

1. Abuzaid AA, Abdoon AM, Aldahan MA, Alzahrani AG, Alhakeem RF, Asiri AM, Alzahrani MH, Memish ZA. Cutaneous leishmaniasis in Saudi Arabia: a comprehensive overview. Vector Borne Zoonotic Dis (Larchmont, NY). 2017; 17(10):673-84

2. Anversa L, Tiburcio MGS, Richini-Pereira VB, Ramirez LE. Human leishmaniasis in Brazil: a general review. Rev Assoc Med Bras (1992). 2018;64(3):281-9
3. Burza S, Croft SL, Boelaert M. Leishmaniasis. Lancet (London, England). 2018;392(10151):951-70.

4. Sarkari B, Hatam G, Ghatee M. Epidemiological features of visceral leishmaniasis in Fars province, southern Iran. Iran J Public Health. 2012:41(4):94.

5. Sarkari B, Naraki T, Ghatee MA, Abdolahi Khabisi S, Davami MH. Visceral Leishmaniasis in Southwestern Iran: a retrospective clinico-hematological analysis of 380 consecutive hospitalized cases (1999-2014). PLoS ONE. 2016:11(3):e0150406.

6. Shokri A, Fakhar M, Teshnizi SH. Canine visceral leishmaniasis in Iran: a systematic review and meta-analysis. Acta Trop. 2017;165:76-89.

7. Mohebali M. Visceral leishmaniasis in Iran: review of the epidemiological and clinical features. Iran J Parasitol. 2013;8(3):348.

8. Norouzinezhad F, Ghaffari F, Norouzinejad A, Kaveh F, Gouya MM. Cutaneous leishmaniasis in Iran: results from an epidemiological study in urban and rural provinces. Asian Pac J Trop Biomed. 2016;6(7):614-9.

9. Davami MH, Motazedian MH, Sarkari B. The changing profile of cutaneous leishmaniasis in a focus of the disease in Jahrom district, southern Iran. Ann Trop Med Parasitol. 2010;104(5):377-82.

10. Ponte-Sucre A, Gamarro F, Dujardin JC, Barrett MP, Lopez-Velez R, GarciaHernandez R, Pountain AW, Mwenechanya R, Papadopoulou B. Drug resistance and treatment failure in leishmaniasis: a 21st century challenge. PLoS Negl Trop Dis. 2017;11(12):e0006052.

11. Pourmohammadi B, Motazedian MH, Handjani F, Hatam GH, Habibi S, Sarkari B. Glucantime efficacy in the treatment of zoonotic cutaneous leishmaniasis. Southeast Asian J Trop Med Public Health. 2011:42(3):502-8

12. Soleimanifard S, Arjmand R, Saberi S, Salehi M, Hejazi SH. Treatment outcome of the drug-resistant zoonotic cutaneous leishmaniasis by glucantime. Adv Biomed Res. 2017;6:17.

13. Bahmani M, Saki K, Ezatpour B, Shahsavari S, Eftekhari Z, Jelodari M, Rafieian-Kopaei M, Sepahvand R. Leishmaniosis phytotherapy: review of plants used in Iranian traditional medicine on leishmaniasis. Asian Pac J Trop Biomed. 2015;5(9):695-701.

14. Shamsi M, Abbasi N, Mohajer A, Hoseini M, Rafieian-Kopaei M. The most important native medicinal plants effective against cutaneous leishmaniasis in mouse. Int J Life Sci Pharma Res. 2018;8(2):P1-7.

15. Aref HL, Salah K, Chaumont JP, Fekih A, Aouni M, Said K. In vitro antimicrobial activity of four Ficus carica latex fractions against resistant human pathogens (antimicrobial activity of Ficus carica latex). Pak J Pharm Sci. 2010;23(1):53-8.

16. Badgujar SB, Patel VV, Bandivdekar AH, Mahajan RT. Traditional uses, phytochemistry and pharmacology of Ficus carica: a review. Pharm Biol. 2014;52(11):1487-503.

17. Elsayed AM, Hegazy UM, Hegazy MG, Abdel-Ghany SS, Salama WH, Salem AM, Fahmy AS. Purification and biochemical characterization of peroxidase isoenzymes from Ficus carica latex. Biocatal Agric Biotechnol. 2018;16:1-9.

18. Kramer DE, Whitaker JR. Ficus enzymes II. Properties of the proteolytic enzymes from the latex of Ficus carica variety Kadota. J Biol Chem. 1964:239(7):2178-83.

19. Mawa S, Husain K, Jantan I. Ficus carica L. (Moraceae): phytochemistry, traditional uses and biological activities. Evid Based Complement Altern Med. 2013. https://doi.org/10.1155/2013/974256.

20. Azami H, Malek-Hosseini S, Taghi MM, Zareinejad M, Amirghofran Z. Antitumor activity and immunomodulatory effects of Ficus carica latex. J Shahid Sadoughi Univ Med Sci. 2020. https://doi.org/10.18502/ssu. v28i12.5776.

21. Camero M, Marinaro M, Lovero A, Elia G, Losurdo M, Buonavoglia C, Tempesta M. In vitro antiviral activity of Ficus carica latex against caprine herpesvirus-1. Nat Prod Res. 2014;28(22):2031-5.

22. de Amorin A, Borba HR, Carauta JP, Lopes D, Kaplan MA. Anthelmintic activity of the latex of Ficus species. J Ethnopharmacol. 1999;64(3):255-8.

23. Ghanbari A, Le Gresley A, Naughton D, Kuhnert N, Sirbu D, Ashrafi $\mathrm{GH}$. Biological activities of Ficus carica latex for potential therapeutics in Human Papillomavirus (HPV) related cervical cancers. Sci Rep. 2019;9(1):1-11.

24. Hashemi S, Abediankenari S, Ghasemi M, Azadbakht M, Yousefzadeh Y, Dehpour A. The effect of fig tree latex (Ficus carica) on stomach cancer line. Iran Red Crescent Med J. 2011;13(4):272. 
25. Shahinuzzaman M, Yaakob Z, Anuar FH, Akhtar P, Kadir N, Hasan AM, Sobayel K, Nour M, Sindi H, Amin N. In vitro antioxidant activity of Ficus carica L. latex from 18 different cultivars. Sci Rep. 2020;10(1):1-14.

26. Mavlonov G, Ubaidullaeva KA, Rakhmanov M, Abdurakhmonov IY, Abdukarimov A. Chitin-binding antifungal protein from Ficus carica latex. Chem Nat Compd. 2008;44(2):216-9.

27. Chung IM, Kim SJ, Yeo MA, Park SW, Moon HI. Immunotoxicity activity of natural furocoumarins from milky sap of Ficus carica L. against Aedes aegypti L. Immunopharmacol Immunotoxicol. 2011;33(3):515-8.

28. Stepek G, Lowe AE, Buttle DJ, Duce IR, Behnke JM. In vitro anthelmintic effects of cysteine proteinases from plants against intestinal helminths of rodents. J Helminthol. 2007;81(4):353-60.

29. Ezatpour B, Saedi Dezaki E, Mahmoudvand H, Azadpour M, Ezzatkhah F. In vitro and in vivo antileishmanial effects of Pistacia khinjuk against Leishmania tropica and Leishmania major. Evid Based Complement Altern Med. 2015. https://doi.org/10.1155/2015/149707.
30. Saleem O, Abdul-Baqi J, Ismail AH. The effect of some medical plant extracts on the intercellular form of Leishmania. J Basrah Res (Sciences). 2007;33(4A):89-92

31. Raskovic B, Lazic J, Polovic N. Characterisation of general proteolytic, milk clotting and antifungal activity of Ficus carica latex during fruit ripening. J Sci Food Agric. 2016;96(2):576-82.

32. Saeed MA, Sabir A. Irritant potential of triterpenoids from Ficus carica leaves. Fitoterapia. 2002;73(5):417-20.

\section{Publisher's Note}

Springer Nature remains neutral with regard to jurisdictional claims in published maps and institutional affiliations.
Ready to submit your research? Choose BMC and benefit from:

- fast, convenient online submission

- thorough peer review by experienced researchers in your field

- rapid publication on acceptance

- support for research data, including large and complex data types

- gold Open Access which fosters wider collaboration and increased citations

- maximum visibility for your research: over $100 \mathrm{M}$ website views per year

At BMC, research is always in progress.

Learn more biomedcentral.com/submissions 